\title{
Biosolids Soil Application: Agronomic and Environmental Implications
}

\author{
Robert Edwin White, ${ }^{1}$ Silvana I. Torri, ${ }^{2}$ and Rodrigo Studart Corrêa ${ }^{3}$ \\ ${ }^{1}$ Department of Agriculture and Food Systems, The University of Melbourne, Melbourne, VIC 3010, Australia \\ ${ }^{2}$ Department of Natural Resources and Environment, University of Buenos Aires, Buenos Aires C1417 DSE, Argentina \\ ${ }^{3}$ Department of Ecology, University of Brasilia, 70910-900 Brasilia, DF, Brazil
}

Correspondence should be addressed to Robert Edwin White, robertew@unimelb.edu.au

Received 29 October 2011; Accepted 29 October 2011

Copyright (c) 2011 Robert Edwin White et al. This is an open access article distributed under the Creative Commons Attribution License, which permits unrestricted use, distribution, and reproduction in any medium, provided the original work is properly cited.

Increasing urbanization and industrialization have resulted in a dramatic increase in the volume of wastes generated worldwide, particularly of sewage sludge or biosolids generated as a byproduct from wastewater treatment. Waste management has become a major environmental challenge, and land application of biosolids is generally considered the best option of disposal because it offers the possibility of recycling plant nutrients, provides organic material, improves a soil's chemical and physical properties, and enhances crop yields. However, the benefits from biosolids application have to be weighed against potential deleterious effects such as risks of excessive leaching of nitrate, contamination of soils and crops with human pathogens and heavy metals, nutritional disorders in crops, increase of soil salinity, contamination of groundwater with pesticides, hormones, and pharmaceuticals, and decreased stability of native soil organic matter. For these reasons, this special issue focuses on the agronomic and environmental implications of soil application of biosolids and presents the most recent scientific information on the subject. Papers in this special issue cover various aspects of the release of nutrients from biosolids and their effect on the growth of cereal and fruit crops, pasture, and trees on a range of soils in diverse locations. Papers also report on the residual nutrient effects of biosolids, their release of potentially damaging heavy metals, and effects on soil organisms, thus providing a broad view of the soil-agronomic advantages and environmental implications of recycling organic matter and nutrients from sewage treatment systems into soils.

The paper made by W. Bettiol and R. Ghini describes and discusses the impacts of sewage sludge in tropical soils of Brazil. A multiyear comparison was developed with the application of sewage sludge on a corn crop, providing the same, two, four, or eight times the recommended rate of $\mathrm{N}$ application. Their results indicated that the amount of sewage sludge used in agricultural areas must be calculated on the basis of the $\mathrm{N}$ crop needs, and annual applications must be avoided to prevent overapplication.

D. B. Wester and coworkers conducted a 10-year study of the effects of different application rates of biosolids on soil properties, forage production and grazing animal behavior and management in the Chihuahuan Desert rangelands. Biosolids increased soil water infiltration and reduced soil erosion. Effects on soil water quality were generally observed only at the highest application rates. Biosolids increased soil nitrate-nitrogen, which moved from surface to subsurface depths at different rates according to the season, and increased forage production for up to four years following a single application. Grazing animals spent more time grazing, ruminating, and resting in biosolids-treated areas, and positive effects on average daily weight gain were observed during periods of higher rainfall. Their results suggested that annual biosolids application rates of 18 to $36 \mathrm{Mg} \mathrm{ha}^{-1}$ are appropriate for desert rangelands.

L. C. Ceolato and coworkers evaluated the changes in soil attributes and uptake of nutrients by surinam grass (Brachiaria decumbens) when liquid sewage sludge was applied on a Paleudult soil during four years. They reported that land application of liquid sewage sludge did not alter soil organic matter nor exchangeable $\mathrm{K}$ in the top $40 \mathrm{~cm}$ of soil. Sludge application increased soil $\mathrm{pH}$, base saturation, labile $\mathrm{P}$, and available $\mathrm{Zn}$ but did not change the concentrations of 
available $\mathrm{B}, \mathrm{Cu}, \mathrm{Fe}$, and $\mathrm{Mn}$ at $0-20 \mathrm{~cm}$ and $20-40 \mathrm{~cm}$ depths. They concluded that liquid sewage sludge was a source of $\mathrm{N}$, $\mathrm{K}, \mathrm{P}, \mathrm{Ca}, \mathrm{Mg}$, and $\mathrm{Zn}$ for the grass but decreased leaf $\mathrm{Mn}$ concentration.

C. G. Cogger and coworkers estimated nitrogen availability of three different heat-dried biosolids to determine whether current guidelines for application rates in the Pacific Northwest of the USA were appropriate. Forage yield and N uptake of tall fescue (Festuca arundinacea) were measured for two growing seasons following surface application of heatdried biosolids on a mesic Vitrandic Haploxeroll soil. Three rates of urea and a zero- $\mathrm{N}$ control were used to calculate $\mathrm{N}$ fertilizer efficiency regressions. Plant-available $\mathrm{N}$ (estimated as urea $\mathrm{N}$ equivalent) in the application year for two biosolids exceeded $60 \%$ of total $\mathrm{N}$ applied, while the urea $\mathrm{N}$ equivalent for the third biosolid was 45\%. Residual (second-year) urea $\mathrm{N}$ equivalent ranged from 5 to $10 \%$. Their research showed that some heat-dried materials substantially exceeded the 35 to $40 \%$ estimated mineralization rates of the guidelines.

Similarly, T. A. Sogn and L. E. Haugen explored the potential of modeling to predict the rate of $\mathrm{N}$ mineralization of sewage sludges and other organic waste products in several soils under field conditions. The model chosen was the SOILN_NO model, which they first calibrated using $\mathrm{N}$ mineralization data measured in a laboratory experiment. Then, the calibrated model was tested against nitrate-leaching data from soil lysimeters growing barley, with added organic waste and exposed to natural climatic conditions during three growing seasons. The SOILN_NO model reproduced relatively well the nitrate leaching from some of the soils but failed with others. The calibrated model usually underestimated the measured nitrate leaching. The authors concluded that SOILN_NO calibrated with data from simple incubation experiments in the laboratory could not be used directly to predict N-leaching following organic waste application in natural production systems. These results emphasized the need for site and systemspecific data for model calibration.

P. H. Muller Silva and coworkers assessed the effects of dry and wet sewage sludges on the growth and nutrient cycling of Eucalyptus grandis plantations in Brazil. Biomass production and nutrient cycling were studied over 36 months comparing wet sewage sludge, dry sludge, mineral fertilizer, and no fertilizer applications. The two types of sludges and mineral fertilizer were comparable in increasing tree biomass, which was significantly greater than in the control treatment. Sewage sludge application positively affected leaf litter production and significantly increased nutrient transfer among the components of the ecosystem.

The effect of biosolids on pasture and vineyard production was examined by D. Nash and coworkers in southeastern Australia. At both sites, soil $\mathrm{Cd}, \mathrm{Cu}$, and $\mathrm{Zn}$ concentrations increased linearly with biosolids application rates, although not to the extent of exceeding soil quality guidelines. Biosolids marginally increased soil $\mathrm{C}$ and $\mathrm{N}$ concentrations at the pasture site but significantly increased soil P concentrations. With lower overall soil fertility in the vineyard, biosolids increased soil $\mathrm{C}, \mathrm{N}$, and $\mathrm{P}$ concentrations. At neither site did biosolids application affect soil microbial activity. Biosolids increased pasture production compared to the unfertilized control but had little effect on grape production or quality. Interestingly, over the 3year trial, there was no difference in pasture production between biosolids-treated plots and those receiving inorganic fertilizer, suggesting that biosolids could be used as an alternative to inorganic fertilizer in this region.

L. A. Junqueira Teixeira and coworkers investigated the effects of biosolids application on the chemical properties of a Yellow Oxisol and on the nutrient concentrations of banana leaves during the first cropping cycle. They concluded that biosolids could completely substitute for mineral $\mathrm{N}$ and P fertilizer for banana growth. However, soil exchangeable $\mathrm{K}$ and leaf $\mathrm{K}$ concentration must be monitored in order to avoid $\mathrm{K}$ deficiency. No risk of an increase in heavy metal $(\mathrm{Cr}$, $\mathrm{Ni}, \mathrm{Pb}, \mathrm{Cd}$ ) concentrations in the index-leaf was observed when biosolids were applied at the recommended rate for $\mathrm{N}$.

R. T. Koenig and coworkers compared applications of biosolids and $\mathrm{N}$ fertilizer on the growth of various winter wheat (Triticum aestivum) cultivars under diverse rainfalls at three locations in Washington State, USA. Although biosolids produced higher grain yields than inorganic $\mathrm{N}$ fertilizer, grain protein content with biosolids was either equal to or less than that with inorganic $\mathrm{N}$. The results indicated the potential to improve dryland winter wheat yields with biosolids compared to inorganic $\mathrm{N}$ alone, but perhaps not to increase the grain protein concentration of hard wheat when biosolids are applied immediately before planting.

The feasibility of using fly ash and composted biosolids as a source of Fe for hybrid poplars grown on a calcareous soil was examined by K. Lombard and coworkers. Both amendments improved soil and plant Fe. Other heavy metals were below EPA regulations, but high B levels were noted in leaves of trees treated at the highest fly ash rate. The $\mathrm{pH}$ increased in fly ash soil, and salinity increased in biosolids-treated soil. Chlorosis rankings improved in poplars amended with both products, although composted biosolids offered the most potential for improving the $\mathrm{Fe}$ supply to trees without the need for expensive synthetic inputs.

Areas reclaimed for agricultural uses following coal mining often receive biosolids applications to increase soil organic matter and fertility. J. O. Miller and coworkers studied the transport of $\mathrm{Cu}$ and $\mathrm{Zn}$ in solution and colloidal phases in reclaimed and undisturbed soils in Virginia and Kentucky, USA. Transport of $\mathrm{Cu}$ and $\mathrm{Zn}$ was observed in both the solution and colloidal phases, where the presence of unweathered spoil material and biosolids amendments contributed to higher metal release into these fractions. Most of the mobile $\mathrm{Cu}$ moved in the colloidal phase in contrast to $\mathrm{Zn}$, which moved predominantly in solution. Because the colloid-bound $\mathrm{Cu}$ was exchangeable in ammonium acetate, it may be released into groundwater. Similarly, the effects of disposing water-treatment sludge on mined areas and the consequences for groundwater were investigated by $\mathrm{R}$. C. A. Moreira and coworkers. They analyzed more than 50 parameters in soil and water and found migration of dissolved solids from stockpiled sludge towards groundwater. 
Y. Y. Min and coworkers applied anaerobically digested slurry (ADS) to soil to evaluate its effects in mitigating crop damage from parasitic nematodes. Tomatoes grew better in pots supplied with ADS than in those supplied with chemical fertilizer and the control; damage caused by a root-knot nematode was significantly lower in ADS-treated soil. For field-grown radish, nematode damage was 30\% and 50\% lower in ADS-treated fields than in the control in 2007 and 2009, respectively, but not in 2008. These results suggested that application of ADS might be feasible for mitigating nematode damage, but the rate and timing should be considered further to determine the best application method.

The effect of biosolids on the earthworm Eisenia fetida and the springtail Folsomia candida was studied by N. Artuso and coworkers. Biosolids did not cause mortality of adult earthworms when applied at 2 and $5 \mathrm{tha}^{-1}$ but did at 10 and $20 \mathrm{tha}^{-1}$. Biosolids rates from 2 to $10 \mathrm{tha}^{-1}$ did not impact on the number of adult springtails, but there were significantly fewer adults at $20 \mathrm{tha}^{-1}$. Compared with controls, the numbers of juvenile springtails were significantly decreased even for biosolids applied at the $2 \mathrm{tha}^{-1}$. The negative effect of higher rates of biosolids on earthworms was not related to heavy metal concentrations in the biosolids. The authors concluded that biosolids applied at legal low rates are unlikely to be detrimental to earthworms or adult springtails but could be detrimental to springtail reproduction.

L. Jäderlund and coworkers evaluated the ability of two different strains of the pathogenic bacterium Campylobacter jejuni to survive in cattle slurry and soil amended with cattle slurry, as well as to infect spinach plants grown in this soil. Irrespective of the bacterial inoculation dose or strategy employed, the $C$. jejuni content in soil remained relatively low and constant, whereas the majority of $C$. jejuni cells applied to spinach leaves could be recovered during the whole evaluation period of 21 days.

While a significant amount of work has been conducted to assess the concentration of pollutants in soils and waterways near land that has been amended with biosolids, much less research investigating emissions to the atmosphere is available in the literature. S. M. Donovan and coworkers investigated the use of a flux chamber technique to measure soil-atmosphere gas exchanges from the application of three different types of biosolids to UK soils and presented preliminary results.

Cocomposting of olive oil solid residue and the treatment of wastewater from olive oil production by application to reed beds were studied by A. A. Zorpas and coworkers. This process is proposed as an integrated method for the treatment of wastewater containing highly organic and toxic pollutants under warm climatic conditions. Experimental results indicated that the olive mill wastewater was detoxified at the end of a Fenton oxidative process. The optimum combination of cocomposted material of olive oil solid residue with the treated olive mill wastewater was suitable for agricultural purposes.

R. de O. Munhoz and coworkers dealt with the build up of biosolids phosphorus in a Haplorthox soil in Brazil. They investigated the matter by the sorption isotherm and the sequential fractionation techniques. Samples of Haplorthox soil under corn crop were collected from an experimental field cultivated for two years after two applications of biosolids. Results showed the biosolids application had decreased soil $\mathrm{P}$ binding energy and changed $\mathrm{P}$ fractions distribution. $\mathrm{P}$ labile fractions $\left(\mathrm{P}-\mathrm{CaCl}_{2}\right.$ and $\left.\mathrm{P}-\mathrm{NaHCO}_{3}\right)$ and moderately labile fraction $(\mathrm{P}-\mathrm{NaOH})$ increased by $11.2 \%$ and $20.3 \%$, respectively, at the expense of the most resistant $\mathrm{P}$ fraction.

Robert Edwin White

Silvana I. Torri

Rodrigo Studart Corrêa 

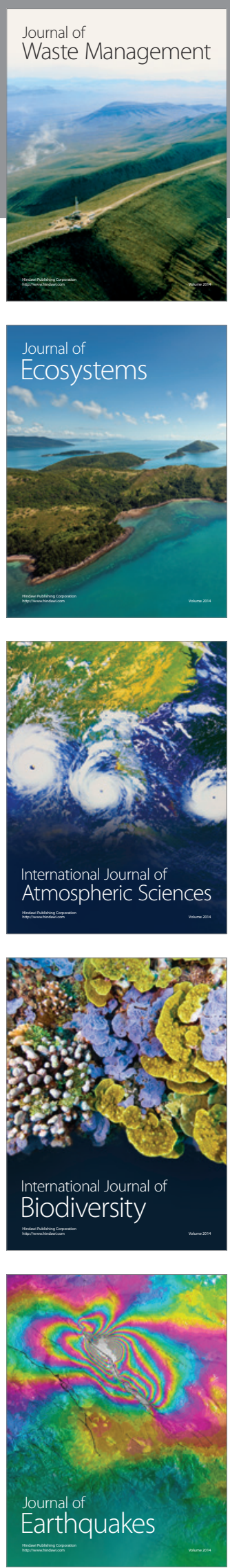
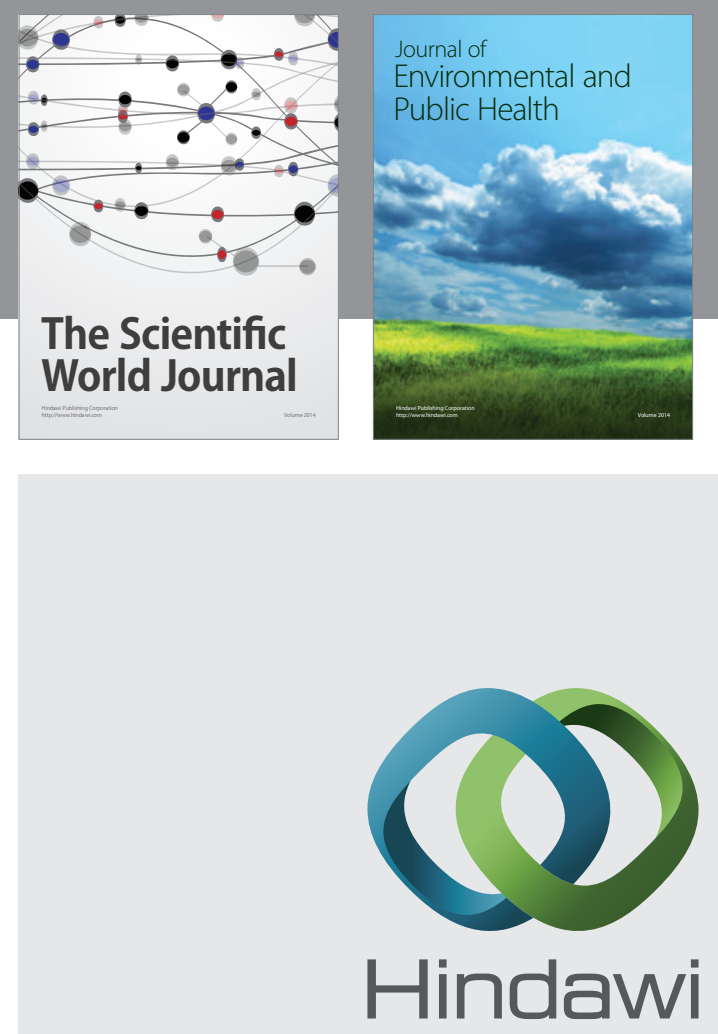

Submit your manuscripts at

http://www.hindawi.com
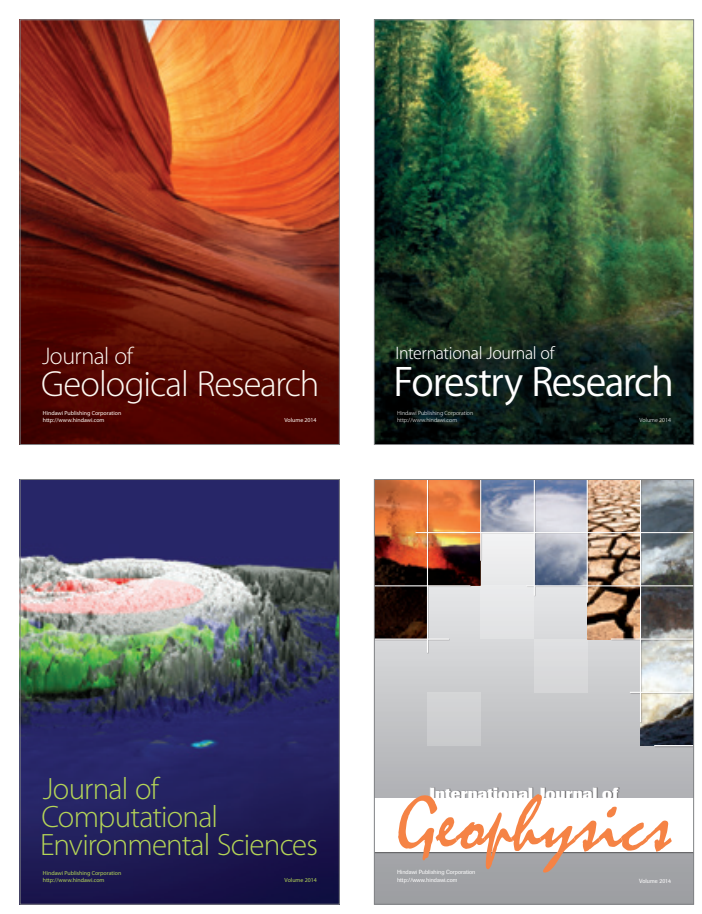
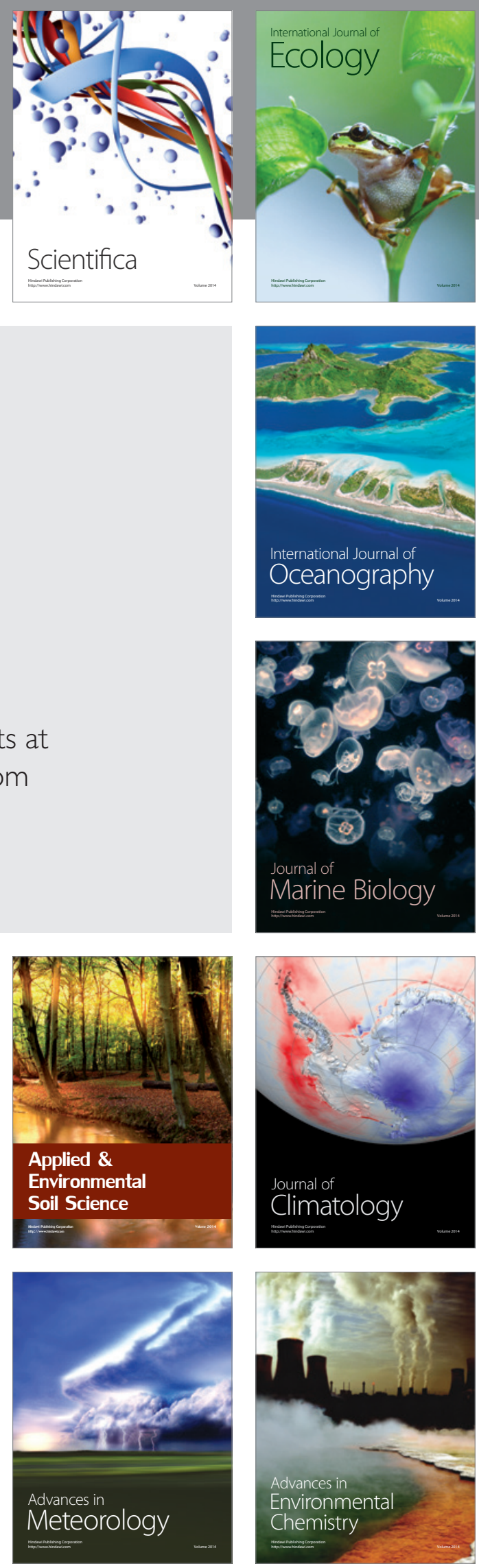